Fixed Point Theory, 21(2020), No. 2, 595-610

DOI: $10.24193 /$ fpt-ro.2020.2.42

http://www.math.ubbcluj.ro/ nodeacj/sfptcj.html

\title{
APPLICATIVE APPROACH OF FIXED POINT THEOREMS TOWARDS VARIOUS ENGINEERING PROBLEMS
}

\author{
VISHAL JOSHI*, DEEPAK SINGH** AND ADITYA SINGH*** \\ *Department of Mathematics, Jabalpur Engineering College, Jabalpur (M.P.), India \\ E-mail: joshinvishal76@gmail.com \\ ** Department of Applied Sciences, NITTTR, Under Ministry of HRD, \\ Govt. of India, 462002 Bhopal (M.P.), India \\ E-mail: dk.singh1002@gmail.com \\ *** Department of Civil Engineering, Indian Institute of Technology (IIT), Indore, India \\ E-mail: ce160004003@iiti.ac.in
}

\begin{abstract}
Utilization of fixed point theory, especially to Engineering problems, is of prime concern in recent times. In this article, we aim to firstly establish some original fixed point results in the metric like spaces and then utilize the same to solve those problems which emphasize primarily the applications for the existence of the solution of equations arising in Rocket science, Electrical engineering and, Mechanical engineering. In this article, offered contractive conditions are of general type, having index $l \in \mathbb{N}$ on underlying mapping which refine and expand various results in the existing theory and thereby giving a pathway to applications-based problems. Moreover, to address conceptual depth within this approach, we supply illustrative examples where necessary, which is, of course, of interest of Engineers and Mathematicians. Computer simulation is adopted to verify the contractive conditions giving more-in-depth insight. We suggest some open problems for future work on the application of fixed point theory.
\end{abstract}

Key Words and Phrases: Fixed point, metric-like spaces, $F$-contraction, $l-F$ type Suzuki contraction.

2010 Mathematics Subject Classification: 47H10, 54H25.

\section{REFERENCES}

[1] A. Abdon, D. Baleanu, Application of fixed point theorem for stability analysis of a nonlinear Schrodinger with Caputo-Liouville derivative, Filomat, 31(8)(2017), 2243-2248.

[2] A. Ahmed, J.J. Nieto, V. Venktesh, Fractional electrical circuits, Adv. Mech. Eng., 7(12)(2015), 1-7.

[3] A. Amini-Harandi, Metric-like spaces, partial metric spaces and fixed points, Fixed Point Theory Appl., 2012(2012), 204.

[4] A. Halabi, I. Sabri, Information theory and its application to pattern recognition in image processing, International Journal of Engineering Inventions, 1(2012), 14-18.

[5] S.M. Jung, J.M. Rassias, A fixed point approach to the stability of a functional equation of the spiral of Theodorus, Fixed Point Theory Appl., 2008(2008), 945010.

[6] E. Karapinar, M.A. Kutubi, H. Piri, D. O'Regan, Fixed point of conditionally F-contraction in complete metric-like spaces, Fixed Point Theory Appl., 2015(2015), 126. 
[7] M. Moghadam, Existence of a non-trivial solution for fourth-order elastic beam equations involving Lipschitz non-linearity, Cogent Math., 3(2016), 1226040.

[8] D. O'Regan, N. Shahzad, R.P. Agarwal, Fixed point theory for generalized contractive maps on spaces with vector-valued metrics, Fixed Point Theory and Applications, (Eds. Y.J. Cho, J.K. Kim, S. M. Kang), Vol. 6, Nova Sci. Publ., New York, 2007, 143-149.

[9] E. Ozgur, I. Karaca, Banach fixed point theorem for digital images, J. Nonlinear Sci. Appl., 8-3(2015), 237-245.

[10] H. Piri, P. Kumam, Some fixed point theorems concerning F-contraction in complete metric spaces, Fixed Point Theory Appl., 2014(2014), 210.

[11] I.A. Rus, A. Petruşel, G. Petruşel, Fixed Point Theory, Cluj University Press, 2008.

[12] I.A. Rus, A. Petruşel, M.A. Şerban, Weakly Picard operators: equivalent definitions, applications and open problems, Fixed Point Theory, 7(2006), no. 1, 3-22.

[13] N.A. Secelean, Iterated function system consisting of F-contractions, Fixed Point Theory Appl., 2013(2013), 277.

[14] D. Singh, V. Chauhan, R. Wangkeeree, Geraghty type generalized F-contractions and related applications in partial b-metric spaces, Int. J. Anal., 2017(2017), 14.

[15] D. Singh, V. Joshi, M. Imdad, P. Kumam, Fixed point theorems via generalized F-contraction with applications to functional equations occurring in dynamic programming, J. Fixed Point Theory Appl., 19(2)(2017), 1453-1479.

[16] D. Wardowski, Fixed points of a new type of contractive mappings in complete metric spaces, Fixed Point Theory Appl., 2012(2012), 94.

[17] Wei-Chau Xie, Differential Equations for Engineers, Cambridge University Press, 2010.

Received: October 26, 2019; Accepted: December 20, 2019. 
